\title{
Can Industrial Policy Foster Innovation in Renewable Energy Technologies in the OECD and in EU Regions?
}

Pitelis, Alkis - Theonas*; Vasilakos, Nicholas**; Chalvatzis, Konstantinos***; Pitelis, Christos

N. ${ }^{* * * *}$

* Corresponding author. University of East Anglia, Norwich Business School, Earlham Rd, Norwich NR4 7TJ; email: a.pitelis@uea.ac.uk

**University of East Anglia, Norwich Business School; email: n.vasilakos@uea.ac.uk

***University of East Anglia, Norwich Business School; email: k.chalvatzis@uea.ac.uk

**** Abu Dhabi University and Brunel University London. College of Business. Salam St. \& 31

St. UAE Academy Campus P.O. Box 6844, Abu Dhabi, United Arab Emirates; email:

christos.pitelis@adu.ac.ae

A B STRACT

Keywords:

Renewable Energy;

Industrial Policy;

Winning

Technologies and

Innovations;

OECD, EU Regions
We cross fertilise scholarship on industrial policy (IP) and renewable energy (RE) innovation and submit that RE serves as a General Purpose Technology that contains more specific RE technologies (RETs). We develop five Hypotheses and provide econometric evidence for the impact of demand-pull, technology-push and systemic IP instruments on different RETs. We test for the role of country experience, for EU North-South regional variations, and for the quality of RE innovations. We employ a large data set for thirtyfour OECD countries and find support for our theory-derived hypotheses. 


\section{Acknowledgements}

We are grateful to the organisers and participants to the Bath Workshop on April $26^{\text {th }}, 2018$, and the Cambridge conference on July $12^{\text {th }}-13^{\text {th }}, 2018$, where earlier versions of this paper have been presented, for useful feedback and discussions. We are also grateful to the editors of CJRES and the guest Editors of the Special Issue for feedback and support throughout the process. Last but not least, we would like to thank the two anonymous referees for their very useful feedback. Alkis-Theonas Pitelis is especially thankful to the Onassis Foundation (Greece) for the financial support received. Nicholas Vasilakos gratefully acknowledges financial support towards this project from the European Union's Horizon 2020 research and innovation programme under grant agreement 776868. Konstantinos Chalvatzis would like to acknowledge the financial support by the project TILOS (Horizon 2020 Low Carbon Energy Local/small-scale storage LCE-08-2014) by the European Union \& Horizon 2020 research and innovation programme under grant number 646529. Errors are ours. 


\section{Introduction}

At the time of writing this paper, Europe together with most of the northern hemisphere were experiencing one of the hottest summers in their history, widely believed to be a result of ongoing anthropogenic climate change (World Weather Attribution, 2018). It is also widely accepted that eliminating emissions especially those from energy use is a first step to climate change mitigation (Rockström et al., 2017). To this end, there has hardly been a more opportune timing to explore the issue of renewable energy (RE) transition for countries and the planet as a whole and the role of public policy in fostering this. This is our aim in this paper.

The recognition of the need for transition from non-RE to RE sources (Smil, 2010) has fuelled discussion about the role of the relative advantages of markets and governments-public policy in bringing about desired change. In the process of growing from a nascent sector into a major contributor of power generation, RE has benefited from both direct public support (e.g. subsidies) and indirect one (e.g. training and awareness programmes). Despite that being a clear instance of Industrial Policy (IP), links between IP, RE and RE Technologies (RETs) had until recently been underexplored. This is acknowledged by the European Union (EU), who has recently enriched its "New Industrial Policy Strategy" with the launch of the EU's Clean Energy Industrial Competitiveness and Innovation Forum for Renewables (European Commission, 2017; European Commission, 2018).

IPs can be any type of government policy aimed to affect industry, often delineated to those policies that seek specifically to improve manufacturing competitiveness, usually in its link and interactions with other sectors such as services and even agriculture (Pitelis, 2015). They can aim to substitute or complement market forces by reinforcing or counteracting the allocative and other effects that existing markets would otherwise bring about. In case of missing markets, IPs can also serve as market creation and co-creation devices - the creation of carbon markets being a case in point. In the EU for example, the basis for a Europe-wide RE policy (REP) was set by the White Paper for a Community Strategy and Action Plan, "Energy for the Future: Renewable Sources of Energy," 
which laid out the overall strategy on RE and set a number of targets, including doubling the share of RE in the EU's gross energy consumption (European Commission, 1997). More recently, the European Commission (2017) has laid out proposals for a new directive for the promotion of the use of energy from RE sources (European Commission, 2016).

The debate about the precise relationship and the role of markets and governments, including multi-country blocks such as the EU, has been central in IP discourse throughout its history (Pitelis, 1994). In brief, mainstream neoclassical economic theory would recommend public sector intervention only in cases of market failures (such as when there exist externalities, monopolistic restrictions, and public goods), and provided that the public sector intervention does not cause more problems than it helps avoid. More recently, scholars in the "new IP" tradition have claimed that missing linkages and connections, filling gaps and learning can be important reasons for government IP interventions, including sectoral. Rodrik (2004) suggested that public policy could be seen as a process of mutual discovery involving both government and market successes and/or failures, as well as learning from these. Stiglitz (1989) has pointed to the ubiquity of market failures but has also highlighted causes and instances of government failures - hence, leaving the question of the effectiveness of public IP not fully resolved. With colleagues, he has more recently emphasised learning as the basis for IP and public-private interactions, see for example Cimoli et al. (2009). Aiginger (2014) critically assesses some recent approaches, their impact on OECD (see Warwick, 2013) and EU IP and recent interest and links with sustainability, climate change, RE and social and economic welfare of regions and countries. This welcomes recognition of the interface between IP and RE, albeit rarely backed up by large dataset based econometric evidence.

In this paper, we aim to address this gap. As noted, the RE sector has been the recipient of public sector support and can serve as a first ambitious step to decarbonisation. Moreover, it lends itself to large dataset-based econometric work, in part because of data availability. Despite of these 
attributes, however, the econometric link between particular IP instruments and RE innovations has remained elusive (Pitelis, 2018).

Traditionally, the idea of targeting focused on specific sectors and/or firms, see Bailey et al. (2018a). Support for RE as a whole can in itself be seen as a form of targeting in that it privileges a particular sector. More recently, the idea of targeting (hence "picking winners") has been extended to picking winning policies and/or winning technologies (Helm, 2010). This form of targeting is relevant to RE since there is a range of RE technologies suitable for the exploitation of different RE sources. In the RE literature there have been a number of studies that have looked at different policy instruments as well as different RETs. None of these however have, to our knowledge, been conceptualised and/or formulated explicitly in the context of IP, or as a test of the targeting/'picking winners' view. Addressing this limitation is an intended contribution of this paper.

In the above context, in this paper we cross-fertilise IP and RE literature, including RE innovations, develop theory and hypotheses and provide large dataset based econometric evidence, by testing for the role of three IP instruments in fostering RE and in specific RETs. We contribute three more innovations. The first is to explore the issue of "country experience" and hence policy "learning" as a factor that mediates the relationship between RE policy and RE innovation. This is important, not least given the extensive debate in IP on the role of discovery and learning. From a public policy perspective, it is critical to know if experience and learning by public policy makers can help improve desired outcomes over time.

The second contribution of this paper is to control for regional variations. This is worth exploring in that, in addition to different policy competencies and experiences, regional blocks may have different comparative advantages or disadvantages in their renewable energy endowments.

Thirdly, we look at the extent to which public policy affects the innovation quality. While commentators focused on the qualitative role of targeting, no one to our knowledge has looked at the quality of innovations. 
The above are conceptually plausible relationships, with far ranging implications. Clearly if public policy fosters inferior innovations, this would impact on the efficacy of the transition, with deleterious societal implications. Regional variations can help develop more sophisticated policies that take into account endowments and comparative advantages. Accordingly, in this paper, we address all of these issues both in theory and by leveraging a unique large-scale database on RE that we have collated for this purpose.

The remainder of the paper is structured as follows: The next section focuses on theory and hypothesis development; section three describes the empirical model, method, data and variables; section four explains the methodology employed; section five presents and discusses the results; and section six provides concluding remarks, limitations and opportunities for further research.

\section{Theory and Hypotheses Development}

\section{Research Background}

Climate change has been described as the biggest of all market failures with potentially detrimental effects to regions, countries and the world at large (Stern, 2007). Given the acknowledged role of fossil fuel-based energy in climate change, but also the fear of free riding (each country refraining from mitigating actions in the expectation that others will), international agreements such as the Kyoto Protocol (United Nations, 1998) and more recently, the Paris Agreement (United Nations, 2015) have sought to bring about requisite international coordination. Moreover, many governments have been pursuing ambitious RE targets, with varying degrees of success (see Flamos, 2010; Viñuales et al., 2016; Honegger and Reiner, 2018).

In contrast to the market failure-based view, others point out that government IP can be complementary to, and supporting of, market forces (Bailey, et al., 2015). In this view, instead of crowding out private investment, government policy and intervention can instead help crowd 
investment, while both governments and private actors can learn, by partaking in a process of discovery (Rodrik, 2004).

In the case of RE transitions, it is acknowledged that the scale of the change involved requires public policies and actions that help trigger corporate interest and leverage private funding in support of RE projects (The Research Council of Norway, 2017). Recent public debates in the USA, for example, on a Green New Deal, rely heavily on the need for large infrastructure projects by the government that will help create the basis and incentivise private sector involvement.

IP has been argued to have had three generations: vertical IP, which focused on backward linkages and 'picking winners'; horizontal IP, which focused on across-the-board market failures as justification for economy-wide, policies; and open-market IP, which focused on missing linkages and connections (Kuznetsov and Sabel, 2011). To these, we could add a fourth, more recent generation that of the market and business ecosystem co-creation. This focuses on the private-public-“third sector" interface and it has two complementary variants. One developed in business strategy literature focuses on the role of private and public entrepreneurs, in co-creating organisations, markets and supporting business ecosystems (Pitelis and Teece, 2016). Another is the place-based approach, which has a similar ecosystem focus and emphasises the role of geography and place/space (Bailey et al., 2018b).

Vertical IP focused on the sectoral and micro levels (Kuznetsov and Sabel, 2011). Burton (1983) had argued that IP has two classes - accelerative and decelerative. The first aimed to "stimulate the birth rate of new business ventures" (Burton, 1983, p. 8), while the latter aimed to reduce the "death rate of senescent companies and industries" (ibid, p. 8). The main weakness of the picking-winners approach was the lack of means of prediction either through standard economic theory or through everyday experience. Nevertheless, the picking-winners approach had been used with some success in Japan and other industrialised countries (Chang, 1993), and a variant of it, employed by China, is evidently bearing fruit (Pitelis, 2015). It is also arguable that, partly because of such successes in a 
number of cases, following a long period of a focus on horizontal policies centred around education, infrastructure, and public-sector efficiency, sectoral and targeting policies are back with vengeance in the EU, the US, the OECD and more widely, (Bailey et al., 2015; Aiginger, 2014).

\section{IP Instruments, Innovation in RETs and Regional Variations in the EU; Theory and Hypotheses Building}

In recent years, EU regional IP has employed the concept of smart specialisation strategies (3S), in which sectors and regions can build on their extant comparative advantages to generate novel competitive ones (Foray, 2015). Market and systemic failures engender under-investment in processes of discovery of new activities with commercial potential. In such cases, the public sector can go beyond horizontal policies to assist regional players to identify, shape, and take advantage of new opportunities (Foray, 2015). This effort, in turn, can help regions become "stickier," that is, have unique and embedded advantages vis-a-vis other regions.

Identifying suitable 3S-type cases requires collaboration between private and public-sector actors, that involves, among others, sharing of information on potential opportunities and critical evaluation of policies. This collaboration entails policy learning in a context of embedded autonomy (Bailey et al., 2018b), that reduces the risks of 'regulatory capture'. This collaboration can be hard to achieve and depends, among other things, on institutional, cultural, and historical factors; hence, there is a need to also look at both policy learning and regional variations. In addition, an important question relates to the policy instruments that are more or less effective in fostering innovation.

In the case of RE policies and echoing the more general debate on IP and specific REP instruments, some have argued that technology-blind instruments, such as sector-wide subsidies, are adequate for fostering innovation (Nordhaus, 2009). In this view, targeting specific RE technologies (RETs) can distort the functioning of carbon markets and hinder efforts to decarbonize the economy (Moselle and Moore, 2011; Less, 2012), while the ensuing social costs might increase compared to their benefits, owing to rent seeking, transaction costs, and information problems (Kalkuhl et al., 
2012). While targeting a particular RET can assist better focus and allocation of often limited resources, targeting involves the opportunity costs of not pursuing other actions and increases the costs of any failures, in that other potentially more effective measures are not pursued. While public policy in general can involve possible government failures, it is arguable that more targeted policies are likely to involve a higher likelihood of failure both in identifying the target and in ensuring that targeting one technology does not negatively impact other technologies. These problems are likely to be more acute the more targeted the policies are, leading to governments picking losers rather than winners (Helm, 2010).

Other scholars have argued that a policy mix that incorporates support for specific RETs may still be preferable (Stern, 2007; Fischer and Newell, 2008; Kalkuhl et al., 2012). This is not least because such a policy mix can foster learning. Questions and challenges remain, however, including what counts as a renewable form of energy - and is, therefore, eligible for support - and how to choose the weights for the different RETs (Helm, 2010). These uncertainties, according to Helm, have resulted in the renewables pork barrel that lobbyists compete for, and therefore, are a major rent-seeking problem. Theory aside, in practice, the current policy mix in the EU implements both general support and technology-specific instruments - a situation that renders the need for evidence all the more urgent.

There is an abundance of case study-based evidence supporting the efficacy of IP in many countries (Chang et al., 2016). There is also a wealth of econometric work in the RE literature showing that general policies and policy instruments have had, overall, positively and significantly affected innovation in RE (Johnstone, 2008; Nesta, 2014; Pitelis, 2018). However, RE-related research has mostly failed to cross-fertilise with the IP literature and tends to be overly evidence-based (i.e. with limited theory). On the other hand, despite recent interest in the IP-RE interface and the role of innovation (Aiginger, 2014), the econometric analysis of the role of IP on RE innovations, widely 
believed to be a key determinant of the efficacy of energy transitions (Pitelis, 2018), has eluded IP scholarship.

Considering the mixed results of targeting sectors, the case for targeting RE needs justification. As we have already mentioned, in recent years, the case for targeting has shifted from specific sectors to policy instruments and/or technologies. The debate concerning general purpose technologies (GPTs) can provide an answer. Bresnahan and Trajtenberg (1995) introduced the concept of GPTs as essentially epoch-defining technologies (such as electricity and the internet) and proposed three criteria for a technology to qualify as a GPT: (1) being pervasive, (2) being capable of ongoing technical improvement, and (3) enabling complementary innovations in other sectors. In other words, GPTs have economy-wide effects, can improve over time, and can help trigger a raft of further innovations. It is arguable that RE qualifies as a GPT, as its adoption can be applicable to virtually every economic activity, from construction to manufacturing and agriculture (consider energy self-sufficient greenhouses and solar pumping) because of its scale flexibility and electricity-transmission potential.

Specifically, most types of renewables come in various sizes without any loss in technical efficiency, owing to either modular design (solar photovoltaic [PV] systems) or engineering configuration (small and large turbines for hydroelectric, geothermal, and wind energy). This attribute of renewables has given rise to distributed energy systems (Alstone et al 2015; Parag and Sovacool, 2016; Li et al., 2018), offering efficiency without the need for a large-scale grid, and making renewables applicable almost everywhere. Beyond scale flexibility, the existing power grid and virtual power markets allow physical and logistical power transmission between producers and consumers, and enables large power consumers to sign private power-purchase agreements with wind or solar farms (see Google, Facebook, etc.), or residential consumers to sign up for RE tariffs (Bird et al., 2017). RETs also improve over time both in terms of their efficiency in energy generation and in terms of their own manufacturing; the solar PV cost, for example, has decreased over twelve-fold in the last decade (Lazard, 2017). The innovation and growth of RE applications have triggered further innovation in a 
range of adjacent sectors. For example, long-distance high-voltage direct-current transmission systems were developed to take RE from remote offshore wind farms to urban consumption centres (Elliott et al., 2016); smart grid applications were developed to facilitate grid services and power multidirectionality (Batista et al., 2017); and grid-scale and off-grid batteries were developed to improve demand and supply timing with intermittent output renewables (Zafirakis et al., 2016; Hills et al, 2018).

Pitelis and Teece (2016) have argued that with regard to IP, it is plausible and in line with historical experience to suggest that public support is likely more effective when it targets GPTs. This is in part because it is easier to grasp (albeit imperfectly) their potential significance (consider electricity and the internet), and in part because private initiatives are unlikely to be forthcoming or effective in such cases owing to the scale of requisite investments and the uncertainty over future returns (the internet being a case in point). By contrast, according to the authors, it is arguable that private businesses possess a comparative advantage in capitalizing on and commercializing these publicly funded GPTs/innovations, precisely because of their pursuit of profitability (consider Facebook, Google, Microsoft).

The above discussion is at an aggregate level of IP and RE. In RE literature there have been debates on the specific instruments that public policy makers may employ to foster RE innovation. This particular area of cross-fertilisation has been underexplored. In this context and in line with the more recent shift of attention in IP research, in this paper we focus on the role of specific REP instruments on RE innovations. Following a longstanding debate, the literature zeroed in three key categories of RE instruments: technology-push (e.g. RD\&D grants and loans, and tax incentives), demand-pull (such as feed-in tariffs and subsidies), and systemic (e.g. tax and subsidy reforms, and the education system) (see Pitelis, 2018, for a more extensive discussion). The first category refers to those instruments that affect the supply side, in particular firms' willingness and capability to innovate. The second aims to boost the overall demand for RE. The third refers to instruments that 
operate economy-wide and help boost the effectiveness of both technology-push and demand-pull instruments. Theoretically, all of these have the capacity to affect positively RETs, the exact relationship being a matter for empirical investigation.

Based on these arguments about both IP as a whole and the theory and evidence behind RE instruments, we propose the following hypothesis.

\section{H1: REP instruments positively affect RE technologies.}

The basis of $\mathrm{H} 1$ is that RETs as a whole are likely to be easier to target and support than particular firms; hence, overall, one would expect that REP instruments positively and significantly affect RETs.

While overall positive, however, the impact of REP instruments on RETs is likely to vary between different REP instruments and different RETs, owing to instrument-, technology-, and country-specific reasons. Given the possible permutations, it would be rather heroic to develop specific individual hypotheses for each of these potentialities, instead the above point to a more generic hypothesis, as follows.

H2: The effect of REP instruments on RETs varies between specific instruments and RETs.

While the above looks rather obvious, we consider it useful to test what the data can reveal about these potentialities.

Despite the significant progress in IP thinking, especially in its fourth generation of 3 , placebased, and ecosystem-based IP, a less well addressed question is whether country experience and hence, learning, can moderate the effectiveness of general and targeted IP. Besides learning from cooperation as per the $3 \mathrm{~S}$ view, countries can also learn from trying, failing, and/or succeeding in terms of particular policies, instruments, and targeting. All these promising ideas can benefit from empirical testing. 
Based on the above, we hypothesise that country experience can help mediate the impact of REP instruments on RETs. In particular, we anticipate that more experienced countries are more successful in terms of fostering RETs.

H3: The impact of targeting particular RETS on RE innovation is mediated by a country's experience.

Another important question concerns regional variations. EU regions differ in terms of RErelated advantages and experiences. A 3S-type view is based on extant advantages, and accordingly, there can exist regional variations in the degree of effectiveness of REPs because of learning, but also because of history and path dependency. For example, one might hypothesize that southern European countries that have been plagued by a higher degree of market and government failures might tend to perform worse, ceteris paribus, precisely because of public-private cooperation and consequently, mutual learning failures, and because of the prevalence of more traditional rent seeking, regulatory capture of transaction costs, and corruption-type cases (Pitelis, 2017).

Accordingly, our fourth hypothesis states that countries and in some cases regional groups of countries sharing similar characteristics, differ in terms of their capacity to design or implement REP. A plausible, albeit arguably controversial, argument, is that a country's degree of development (including institutional and governance development) can be seen as a proxy for its capability to design and implement REPs. If so, one would expect the southern regions (countries) of the EU to be less effective than the northern ones, as a result of their legacy of failures in both the public and private sectors (see also Aiginger, 2014). Hence, we derive the following hypothesis.

H4: The efficacy of targeting RETs differs across North-South EU regions.

Another important question relates to whether the challenges of targeting are not reflected (merely) in terms of failure to foster innovation, but (also or instead) in terms of inducing lowerquality innovations. The critics of the "picking winners" hypothesis have not entertained such a possibility, to the best of our knowledge, and consequently, this has not been tested. It is, however, a 
plausible deduction from a government failure-market distortion point of view, worthy of further exploration and testing.

Our fifth hypothesis accordingly, modifies the argument that a government cannot pick winners by focusing on technologies, not firms or sectors and by suggesting that any failure in picking winners is in terms of fostering lower quality of RE innovations, not necessarily their quantity. This hypothesis is in line with both theory and practice (e.g. the prevalence of investments aimed at taking advantage of a particular government programme) and implies the need to adjust for the quality of innovations emanating from public-sector support. Accordingly, the following hypothesis is derived:

H5: Public support for particular RETs affects negatively the quality of innovation in RETs

While the first two hypotheses have already been proposed and tested in the RE literature (even if not sufficiently cross-fertilised and informed by advances in IP literature), the other three have not been proposed and/or tested before both in general and in the context of a comprehensive data set and econometric techniques in particular. We address these limitations in the next section.

\section{Model and Variables}

\section{Sample Selection}

We constructed a panel consisting of 34 OECD (Organisation for Economic Cooperation and Development) member countries between 1990 and 2014. We chose the OECD based on the diversity of the member countries, and consequently, the diversity of the REP instruments, while including the entire EU, which is widely perceived as a leader in the area of RE policy-making and innovation. We considered 1990 as the starting point of this analysis to capture the effects before and after the signing and ratification of the Kyoto Protocol, which has helped initiate the redirection of innovative activities toward renewables (Rawlins and Allal, 2003). We chose 2014 as the end point of the analysis owing to data restrictions related to patenting activity (it takes a few years for the data to present the actual activity). It is, therefore, prudent to exclude data for the last three years (OECD, 2005). 


\section{Dependent Variable: RE Innovation}

Innovation can be measured both by means of input measures (such as R\&D expenditure) and output (yield)-oriented measures, which account for the results of the innovation process, such as patenting activity (Smith, 2004).

Data on patenting activity is the most commonly employed proxy for innovation activity and the most commonly used measure of innovation (OECD, 2001). We collected patent data from the latest (2016) publicly available online version of the European Patent Office's Worldwide Patent Statistical Database (EPO, 2016) for the OECD. In accordance with the existing literature (Johnstone et al., 2008; Nesta et al., 2014; Pitelis, 2018), the International Patent Classification system was used because it allows distinguishing between inventions across technologies for different RE sources in biomass, geothermal, hydroelectric, solar, and wind energy. Patent Cooperation Treaty patent applications in the international phase, filed directly at the International Bureau of the World Intellectual Property Organisation (WIPO), were also considered. The patents were assigned to a country based on the inventor's address, and the date of the patent was the earliest priority date. A total of 217,393 patents were obtained.

\section{Independent Variables: RE Policies (REPS) and REP Instruments}

Data on REPs were obtained from the International Energy Agency (IEA) database between 1990 and 2014. Policies can target one or more RETs or RE subsectors. For example, in 2000 , the UK introduced the RE Obligation, which targeted all RETs and was applicable across all subsectors (i.e. electricity, heating and cooling, and transport). In the same year, the UK also introduced the Energy Crops Scheme, which targeted only biomass-related technologies and was relevant only to the power and heat subsector. Similarly, in 1990, Germany introduced the Environment and Energy Saving Programme, which provided loans specifically for onshore and offshore wind technologies; for biomass technologies related to power, heat, and transportation; and for solar technologies related to heating. In contrast, Germany's Integrated Climate Change and Energy Programme (2007) targeted 
all RETs across all sectors. In this study, we collected data on five RETs and REP instruments that target electricity.

Instruments were classified into three main categories (technology-push, demand-pull, and systemic). This categorisation was based on a systematic review of the descriptions of each policy (Groba and Breitschopf, 2013; Pitelis, 2018), provided in the policy descriptions in the IEA database; in few cases in which they were not, we consulted the original policy documents and the related literature. Initially, the classification resulted in six categories, one for each technology (i.e. biomass, geothermal, hydroelectric, solar, wind, and an aggregated set for all RETs). These categories were then further combined by summing up RE instruments according to purpose, depending on the targeted RETs, and focus country, resulting in several panel tables. Some policy instruments corresponded to more than one type (e.g. both technology-push and demand-pull), and in such cases, both types were counted. Previous studies have also summed up all implemented policies (see Johnstone et al., 2008; Nesta et al., 2014; Pitelis, 2018;). Our classifications allowed for the treatment of the resulting variables as count variables, as they were not diverse in character.

To test for experience, our third hypothesis, we created an index for experience and learning. We hypothesised that experience and learning can be proxied in terms of the extent of intervention (high and low policy intervention of countries) and used it to test for the impact of experience on the efficacy of targeting. Next, we created two regional dummies for northern and southern European countries to test our fourth hypothesis. Finally, we adjusted for the quality of innovations to explore whether targeting impacts or distorts the innovation outcome.

\section{Control Variables}

RE innovation is likely affected by various other factors besides public policies, and we, therefore, controlled for such other key factors. Returns on an innovation are affected by its potential market. In the case of RE, this tendency is best reflected in trends for electricity consumption. A large growing market for electricity should increase incentives to innovate with respect to RETs. We obtained data 
on household and industrial electricity consumption (in GWh) from the IEA and OECD databases, and we found that both observed and calculated balances exist, which we averaged in this study. To control for market power, we also included an index developed by the OECD related to the market share of the largest generator in the electricity market. We anticipate this index would negatively affect RE innovation, as the higher it is (indicating monopoly), the lower the incentive to innovate will be, as a result of the fear of appropriating the returns from innovations due to monopolistic restrictions (Teece, 1986).

In addition, we included the total government budget allocations for R\&D by socioeconomic objective. This controls for a government's overall tendency to support innovation. Its precise sign is hard to predict because while the more pro-innovation a government is, the more likely it is to incentivise RE innovations, governments can also support non-RE innovations, rendering the interactions hard to predict on an a priori basis. We extracted data from the OECD database for the years under examination (1990-2014) and converted them into constant 2010 USD prices and purchasing power parity. Finally, we augmented our model by including a dummy variable set to unity for the years after the Kyoto Protocol went into force in 2005, to capture changes in expectations on both the future policy context and the global market size for RE (Nesta et al., 2014).

In terms of procedure, we first compared the impact of REP instruments on RE innovation among the OECD and European countries as a whole. In terms of IP intervention, the average annual number of REP policies implemented over the 1990-2014 period was taken, based on which two groups were created, as follows:

High-policy-intervention group: Countries that have implemented more than the average number of REPs of all countries over the sample period (i.e. 4 REPs per year)

Membership rule:

$$
\frac{\sum_{\mathrm{t}=1990}^{2014} \sum_{\mathrm{i}=1}^{5} \mathrm{REP}_{\mathrm{it}}}{n} \geq \frac{\sum_{\mathrm{j}=1}^{34} \sum_{\mathrm{t}=1990}^{2014} \sum_{\mathrm{i}=1}^{5} \mathrm{REP}_{\mathrm{itj}}}{n}
$$


Low-policy-intervention group: Countries that have implemented fewer than the average number of REPs of all countries over the sample period

Membership rule:

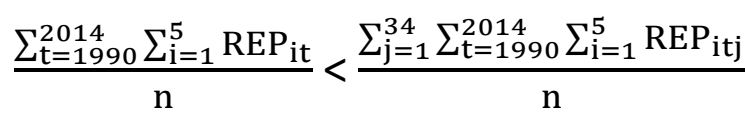

\section{Methodology}

Considering the nature of our dependent variable (number of patents, which is a count variable), we based our estimation strategy on using a conditional negative binomial model for the panel data. Our methodology follows the classic model of Hausman et al. (1984) which augments the basic negative binomial model to include fixed effects. Typically, negative binomial regressions are suitable for use with over-dispersed count variables, especially when the conditional variance of the outcome variable exceeds the conditional mean, as is the case for all the innovation measures used in this study. For instance, in the case of total non-quality adjusted patents, the conditional variance is found to be 6.8 , which is greater than the corresponding conditional mean of 4.8. Figure 1 illustrates the distributional properties of the patent data by renewable technology, whereas table 1 provides summary information about the descriptive statistics of our key variables.

\section{[FIGURE 1 ABOUT HERE]}

\section{[TABLE 1 ABOUT HERE]}

Our sample, which was drawn from the OECD database, included information on all 34 OECD countries over the 1990-2014 period. Our model was designed to evaluate the effect of policy support instruments on the innovation activity of five core RETs: biofuel-, geothermal-, hydroelectric-, solar-, and wind-related technologies. The dependent variable of the regression was, therefore, a vector of length 5 , depicting patent counts by renewable technology. Our core estimation model took the following form:

$$
R E \text { Innovation }_{i, t, T e}=\alpha+R E P_{i t j} \underline{\beta}+X_{i t j} \underline{\gamma}+v_{i}+u_{t}+\varepsilon_{i t j}
$$


To test for the quality of innovations, we employed the ratio of the citations over the average citation performance for that year/country for each technology. The importance of controlling for quality of innovation when assessing policy effectiveness has been raised in several recent papers (Athey and Imbens, 2017; Blind, 2016; Flanagan and Uyarra, 2016), but has not been tested in our context.

\section{Results}

[TABLE 2 ABOUT HERE]

Starting with OECD countries (columns to the left of the Table), we can see that the effects were quite varied and that policy instruments had different levels of success in stimulating innovation, depending on the instrument and technology. Technology-push policy instruments, except for geothermal and wind technologies, had an overall positive and significant effect on innovation. Similarly, demand-pull policy instruments effectively boosted innovation for biofuel-, hydroelectric-, and wind-related technologies, but not so for geothermal- and solar-related technologies. Systemic policy instruments had no significant effect on innovation outcomes except in the case of wind technology, for which the effect was marginally negative. The overall effects were positive and in line with previous research that employed aggregate REPs as independent variables (Pitelis, 2018), and hence, support our first hypothesis. As the aggregate relationship masks the disaggregated effects here, we focused on the latter. The results lend support to our second hypothesis.

Given that OECD is a group of countries with varied approaches to regulatory policy, it is quite possible that pulling together all OECD data may average away some of the key effects that we wish to explain. We addressed this potential concern by splitting our dataset into two smaller groups: highand low-policy-intervention member countries, following again the methodology that we described in section 4 (Table 2, columns on the right). The magnitude and significance of the estimated coefficients were now quite different: technology-push policy instruments were largely ineffective in promoting 
innovation when used by high-intervention OECD countries, unlike demand-pull policy instruments, which were the most effective for this group. The opposite was true for low-intervention countries for which (demand-) technology- (pull) push policy instruments were rather (in)effective. Systemic policy instruments did not significantly and positively affect either of the two groups -in particular, these policy instruments had a negative and significant effect on the high-intervention group, and a positive but insignificant effect on the low-intervention group, across the entire spectrum of renewable technologies. These results support our third hypothesis.

The findings about policy instruments were in line with our theory and those of earlier studies on REPs and RE innovations (Pitelis, 2018). With regard to the systemic instruments in particular, their purported aim is to support the efficacy of demand-pull and technology-push instruments, and in this context, the effects of systemic instruments are likely exhausted in terms of their impact on the other two. Differently put, the observed coefficients for systemic policies show the differential impact of such policies, in addition to their impact through the other two.

[TABLE 4 ABOUT HERE]

Next, we narrowed down our sample to EU member states to evaluate the effect of the same policy instruments on EU energy-innovation outcomes (with and without quality adjustments, as before). The argument for this step was twofold: first, the EU has been at the forefront of using policysupport instruments to stimulate innovation in the RE sector (Sahu, 2015; Schubert et al., 2016). Second, the EU is a much more homogeneous group of countries than the OECD is from a regulatory perspective, which may make it easier to identify links between energy innovation and policy support. The results were very similar to the ones we obtained in our earlier analysis. Again, the use of policy support had an overall positive effect on the quantity of innovation, which, however, was watered down significantly when controlling for quality. We also saw that policy intervention was often more effective in northern than in southern member states, for both high- and low-intervention groups. 
These differences became more pronounced when adjusting for quality of innovations. They may partly reflect climatic and geological differences between the North and the South (for instance, the North of the EU hosts a greater capacity of hydroelectric generation technologies than the South, which affects both the funding and intensity of innovation in relation to these technologies). The results support our fourth hypothesis.

\section{[TABLES 3 AND 5 ABOUT HERE]}

Tables 3 and 5 show a similar set of estimations, this time using a quality-adjusted measure of innovation. This enables us to evaluate the effect of policy intervention on impactful innovation, rather than just its quantity. Our results showed that when controlling for quality of innovation, many of the effects that we described earlier became insignificant. This finding implies that the use of policy support instruments in the OECD over our sample period has been less effective in encouraging impactful innovation in RE technologies than it has been in stimulating activity per se and it supports our fifth hypothesis.

With regard to the control variables, these were mostly in line with theory. In particular, market concentration was negative and significant in the majority of cases; the electricity market size was positive and significant overall with varying degrees of significance; the dummy for the Kyoto Protocol was variable but often positive and significant; the total government budget allocations, the electricity market size, and the dummy for the Kyoto Protocol were all highly contingent and variable.

A summary of our key results and their implications for policy making can be found in Table 6 . Overall, our results were free from the econometric problems that are often associated with countdata estimators. Some of our findings can benefit from further exploration and fine tuning - which is an opportunity for further research. 


\section{Summary, Conclusions and Discussion}

In summary, in this paper we have cross-fertilised the literature in the area of innovation in Renewable Energy (RE) and Industrial Policy (IP). We have applied the concept of 'picking winners' to different IP instruments (demand pull, technology push and systemic) and to different RE technologies (RETs). We have argued that RE as a whole can be described as a general purpose technology that encompasses more specific RETs, such as solar and wind, amongst others. We have provided novel econometric evidence for the impact of IP instruments on innovation in RETs, explored regional variations between the North and South of the EU, and have tested for a more nuanced variant of the 'picking winners' thesis that considers the quality of RE innovations fostered by government intervention. Having developed our conceptual analysis, we have developed and tested five hypotheses using a large dataset for 34 OECD countries.

Overall, our hypotheses were supported by the econometric evidence. More specifically, our results showed that IP instruments positively and significantly affect RETs, with the demand-pull ones being more potent, especially in high-intervention countries. The efficacy of targeting RETs was found to be contingent upon a country's experience, with more experienced countries being more effective. We have also identified, regional variations between the North and the South of the EU, in particular that RE policies of southern countries were on balance less effective in fostering innovation in different RETs. Last but not least we have found that public-policy support may help induce lower-quality innovations. In addition to the above, there were some interesting findings in relation to control variables, notably in the case of market shares (which can be considered a proxy for market power), which was found to hinder RE innovation.

These findings are all fairly significant advances in the field, and they have rather clear, strong, policy implications. In particular, we have found that the efficacy of public policy depends on the chosen instrument hence in order to increase policy impact, policy makers should use a REP mix that mirrors the type of RET they wish to target. Our findings also support the idea that policy makers can 
learn from mistakes, hence the possibility for, and the fear of, mistakes need not be a justification for inaction. In particular, experience and learning matter. Our findings about regional variations in the EU, support the idea that REPs work better within a context of supporting effective governance. Last but not least our test of the more nuanced variant of potential downsides of governments 'picking winners' suggests that policy design and evaluation can be important in ensuring that policy does not lead to (lower quality) innovations merely aimed at taking advantage of the government funding available.

This study has certain limitations, which present opportunities for further research. These include, among others, fine-tuning our proxies for experience, quality, and regional blocks. In addition, for our first hypothesis, we relied on the aggregate evidence on the impact of REP instruments on specific RETs, as opposed to the aggregate effects of all REPs instruments on all RE innovation. This was in part because of earlier extant evidence on this impact (see Pitelis, 2018) and because the aggregated effect masks the nuances of the relationships which we sought to unearth in this paper. (That said, results with the aggregate RE innovation as a dependent variable were aligned with those of earlier studies and supported our arguments). In presenting the results we focused on the key novel ideas and findings, in part because of space considerations and in part because of the multiple possible relationships resulting from the use of the different policy instruments and the different RETs

To conclude, we argue that our paper helps unmask a number of important conceptual and empirical issues and provide evidence in this very important area, that we hope it will generate further interest and will motivate further research. 


\section{References}

Aiginger, K. (2014). Industrial Policy for a Sustainable Growth Path. WIFO Working Papers, No. 469.

Alstone, P., Gershenson, D., \& Kammen, D. M. (2015). Decentralized energy systems for clean electricity access. Nature Climate Change, 5(4), 305-314.

Athey, S., \& Imbens, G. W. (2017). The state of applied econometrics: Causality and policy evaluation. Journal of Economic Perspectives, 31(2), 3-32.

Bailey, D., Coffey, D., Gavris, M., \& Thornley, C. (2018a). Sector-targeting Policies for National Competitiveness: Exploring the Tensions with Place-based Industrial Policy. Conference Back on the Agenda? Industrial Policy Revisited. Cambridge.

Bailey, D., Pitelis, C. N., \& Tomlinson, P. R. (2018b). A place-based developmental regional industrial strategy for sustainable capture of co-created value. Cambridge Journal of Economics, DOI: 10.1093/cje/bey019.

Bailey, D., Cowling, K., \& Tomlinson, P. (Eds.). (2015). New Perspectives on Industrial Policy for a Modern Britain. Oxford: OUP Oxford.

Batista, N. C., Melício, R., \& Mendes, V. M. (2017). Services enabler architecture for smart grid and smart living services providers under industry 4.0. Energy and Buildings, 141, 16-27.

Bresnahan, T., \& Trajtenberg, M. (1995). General purpose technologies 'Engines of growth'? Journal of Econometrics, 65(1), 83-108

Bird, L., Heeter, J., O'Shaughnessy, E., Speer, B., Cook, O., Jones, T., ... Nilson, E. (2017). Policies for Enabling Corporate Sourcing of Renewable Energy Internationally: A 21st Century Power Partnership Report (No. NREL/TP-6A50-68149). Golden, CO (United States): National Renewable Energy Lab.(NREL).

Blind, K. (2016). The impact of regulation on innovation. In J. Edler, P. Cunningham, A. Gok, \& P. Shapira (Eds.), Handbook of Innovation Policy Impact (pp. 450-48). Edward Elgar Publishing.

Burton, J. (1983). Picking Losers...? The political economy of industrial policy. London: Institute of Economic Affairs - Hobart Paper 99.

Chang, H. J. (1993). The political economy of industrial policy in Korea. Cambridge Journal of Economics, 17(2), 131-157.

Chang, Y. C., \& Chen, M. N. (2016). Service regime and innovation clusters: An empirical study from service firms in Taiwan. Research Policy, in press.

Cimoli, M., Dosi, G., \& Stiglitz, J. E. (Eds.). (2009). Industrial Policy and Development: The Political Economy of Capabilities Accumulation. Oxford: Oxford University Press.

Elliott, D., Bell, K. R., Finney, S. J., Adapa, R., Brozio, C., Yu, J., \& Hussain, K. (2016). A comparison of $A C$ and HVDC options for the connection of offshore wind generation in Great Britain. IEEE Transactions on Power Delivery, 798-809. 
EPO. (2016, Spring Edition). PATSTAT - Patent Information Services for Experts. Retrieved from European Patent Office: https://data.epo.org/expert-services/index.html

European Commission. (1997). Energy for the future: renewable sources of energy. White paper for a community strategy and action plan, COM(97) 599 final. European Commission.

European Commission. (2001). Directive 2001/77/EC. European Commission.

European Commission. (2016). Proposal for a DIRECTIVE OF THE EUROPEAN PARLIAMENT AND OF THE COUNCIL on the promotion of the use of energy from renewable sources (recast) COM/2016/0767 final/2 - 2016/0382 (COD. Belgium: European Comission.

European Commission. (2017, December 14). New Industrial Policy Strategy. Retrieved June 01, 2018, from European Commission: https://ec.europa.eu/commission/news/new-industrialpolicy-strategy-2017-sep-18_en

European Commission. (2018, August 1). Launch of the EU Clean Energy Industrial Competitiveness and Innovation Forum for renewables. Retrieved August 20, 2018, from Europa/European Commission: https://ec.europa.eu/info/news/launch-eu-clean-energy-industrialcompetitiveness-and-innovation-forum-renewables-2018-jan-08_en

Fischer, C., \& Newell, R. G. (2008 ). Environmental and technology policies for climate mitigation. Journal of Environmental Economics and Management 55 (2), 142-162.

Flamos, A. (2010). The Clean Development Mechanism - catalyst for wide spread deployment of renewable energy technologies? or misnomer? Environment, Development and Sustainability, 12(1), 89-102.

Flanagan, K., \& Uyarra, E. (2016). Four dangers in innovation policy studies-and how to avoid them. Industry and Innovation, 23(2), 177-188.

Foray, D. (2015). Smart specialisation: Opportunities and challenges for regional innovation policy. London: Routledge.

Hausman, J., Hall, B. H., \& Griliches, Z. (1984). Econometric Models for Count Data With an Application to the Patents-R\&D Relationship. Econometrica, 54, 909-938.

Helm, D. (2010). Government Failure, Rent-Seeking, and Capture: the design of climate change policy. Oxford Review of Economic Policy, 26(2), 182-196.

Hills, J. M., Michalena, E., \& Chalvatzis, K. (2018). Innovative technology in the Pacific: Building resilience for vulnerable communities. Technological Forecasting and Social Change, 129, 1626.

Holland, S. (2014). Europe in Question - and what to do about it. London: Spokesman Books.

Honegger, M., \& Reiner, D. (2018). The political economy of negative emissions technologies: consequences for international policy design. Climate Policy, 18, 306-321.

Johnstone, N., Haščič, I., \& Popp, D. (2008). Renewable Energy Policies and Technological Innovation: Evidence based on patent counts. Environmental and Resource Economics 45:1, 133-155.

Kalkuhl, M., Edenhofer, O., \& Lessmann, K. (2012). Learning or lock-in: Optimal technology policies to support mitigation. Resource and Energy Economics, 34 (1), 1-25. 
Kuznetsov, Y., \& Sabel, S. (2011). New Open Economy Industrial Policy: Making Choices without Picking Winners. The World Bank.

Lazard (2017). Lazard's Levelised Cost of Energy Analysis - Version 11.0. Retrieved August 26, 2018, from LAZARD: https://www.lazard.com/media/450337/lazard-levelized-cost-of-energyversion-110.pdf

Less, S. (2012). Greening the economy - not "green economy". London: Policy Exchange.

Li, X., Chalvatzis, K., \& Stephanides, P. (2018). Innovative Energy Islands: Life-Cycle Cost-Benefit Analysis for Battery Energy Storage. Sustainability, 10(10), 33-71.

Moselle, B., \& Moore, S. (2011). Climate Change Policy - Time for Plan B. London: Policy Exchange.

Nesta, L., Vona, F., \& Nicolli, F. (2014). Environmental policies, competition and innovation in renewable energy. Journal of Environmental Economics and Management 67:3, 396-411.

Nordhaus, W. D. (2009). Designing a friendly space for technological change to slow global warming. Snowmass Conference on Technologies to Combat Global Warming. CO: Snowmass.

OECD. (2001). Using Patent Counts for Cross-Country Comparisons of Technology Outputs. STI Review No. 27, 129-146.

OECD. (2005). Oslo Manual - Guidelines for Collecting and Interpreting Innovation (3d Ed.). OECD Publishing.

Parag, Y., \& Sovacool, B. K. (2016). Electricity market design for the prosumer era. Nature Energy, $1(4), 16-32$.

Pitelis, A. T. (2018). Industrial policy for renewable energy: The innovation impact of European policy instruments and their interactions. Competition and Change, 22(3), 227-254.

Pitelis, C. N. (1994). Industrial Strategy: For Britain, in Europe and the World. Journal of Economic Studies, 21(5), 3-92.

Pitelis, C. N. (2015). DIP-ly Speaking: Debunking 10 Myths and a Business Strategy-Informed Developmental Industrial Policy. In D. Bailey, K. Cowling, \& P. Tomlinson (Eds.), New Perspectives on Industrial Policy for a Modern Britain (pp. 17-40). Oxford: Oxford University Press.

Pitelis, C. N. (2017). Europe in question and the question of Europe-an(d) capitalism: a review of Stuart Holland's 'Europe in Question. Cambridge Journal of Economics, 41(6), 1721-1739.

Pitelis, C. N., \& Teece, D. (2016). Dynamic Capabilities, Developmental Industrial Strategy and The Strategic SCA of Nations. 1-42. Retrieved from https://ssrn.com/abstract=2749110

Pitelis, C. N., \& Teece, D. J. (2009). The (new) nature and essence of the firm. European Management Review, 6(1), 5-15.

Pitelis, C. N., \& Teece, D. J. (2010). Cross-border market co-creation, dynamic capabilities and the entrepreneurial theory of the multinational enterprise. Industrial and Corporate Change, 19(4), 1247-1270.

Rawlins, M., \& Allal, H. (2003). Renewable Energy Technologies and Kyoto Protocol Mechanisms. Belgium: European Commission: EUR 20871. 
Rockström, J., Gaffney, O., Rogelj, J., Meinshausen, M., Nakicenovic, N., \& Schellnhuber, H. J. (2017). A roadmap for rapid decarbonization. Science, 355(6331), 1269-1271.

Rodrik, D. (2004). Industrial Policy for the Twenty-First Century. KSG Working Paper No. RWP04-047, 1-58. Retrieved from https://papers.ssrn.com/sol3/papers.cfm?abstract_id=617544

Sahu, B. K. (2015). A study on global solar PV energy developments and policies with special focus on the top ten solar PV power producing countries. Renewable and Sustainable Energy Reviews, $43,621-634$.

Schubert, S. R., Pollak, J., \& Kreutler, M. (2016). Energy policy of the European Union. London: Palgrave/Macmillan International.

Smil, V. (2010). Energy Transitions: History, Requirements, Prospects. Oxford: Praeger.

Smith, K. (2004). Chapter 6: Measuring Innovation. In J. Fagerberg, D. C. Mowery, \& R. R. Nelson, The Oxford Handbook of Innovation (pp. 148-178). Oxford: Oxford University Press.

Stern, N. (2007). The Economics of Climate Change: The Stern Review. Cambridge: Cambridge University Press.

Stiglitz, J. E. (1989). Markets, Market Failures, and Development. The American Economic Review 79 (2), 197-203.

Teece, D. (1986). Profiting from Technological Innovation: Implications for Integration, Collaboration, Licensing and Public Policy. Research Policy, 15, 285-305.

The Research Council of Norway. (2017, January 11). Horizon 2020 - Public-Private Partnerships (PPPs). Retrieved July 15, 2018, from The Research Council of Norway: https://www.forskningsradet.no/prognetthorisont2020/PublicPrivate_Partnerships_PPPs/1254023914755?d=Touch

United Nations. (1998). Kyoto Protocol to the United Nations Framework Convention on Climate Change. Bonn, Germany: United Nations.

United Nations. (2015). Paris Agreement. Bonn, Germany: United Nations.

Viñuales, J. E., Depletze, J., Reiner, D. M., \& Lees, E. (2016). Climate policy after the Paris 2015 climate conference. Climate Policy, 17(1), 1-8.

Warwick, K. (2013). Beyond Industrial Policy: Emerging Issues and New Trend OECD Science, Technology and Industry Policy Papers, No. 2, . OECD Publishing.

World Bank. (2010). World Development Report: Development and Climate Change. Washington: The International Bank for Reconstruction and Development/The World Bank.

World Weather Attribution. (2018, July 28). Heatwave in northern Europe, summer 2018. Retrieved August 05, 2018, from World Weather Attribution: https://www.worldweatherattribution.org/attribution-of-the-2018-heat-in-northerneurope/

Zafirakis, D., Chalvatzis, K. J., Baiocchi, G., \& Daskalakis, G. (2016). The value of arbitrage for energy storage: Evidence from European electricity markets. Applied Energy, 184, 971-986. 
Figures and Tables

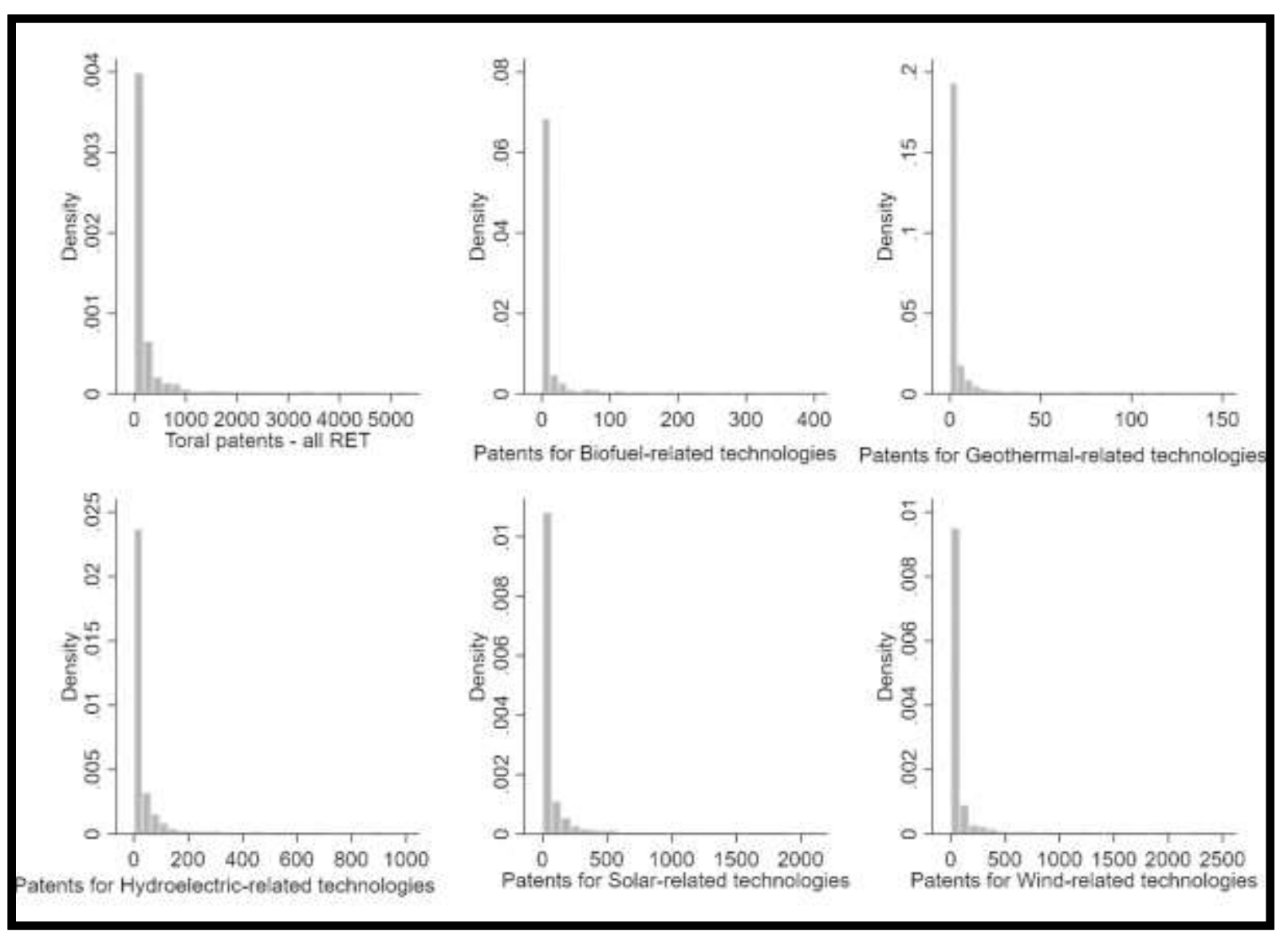

Figure 1: Distributional properties of patent data by renewable technology (Source: Authors after data from PATSTAT (2016) 
Table 1: Summary descriptive statistics for key variables (OECD and EU members)

\begin{tabular}{|c|c|c|c|c|c|c|c|c|}
\hline \multirow[b]{2}{*}{ Variable } & \multicolumn{4}{|c|}{ OECD (34) } & \multicolumn{4}{|c|}{ EU (22) } \\
\hline & Mean & Std. Dev. & Min & Max & Mean & $\begin{array}{l}\text { Std. } \\
\text { Dev. }\end{array}$ & Min & Max \\
\hline Renewable energy patents granted (per year) & 255.76 & 623.52 & 0.00 & 5296.00 & 205.84 & 511.46 & 0.00 & 4547.00 \\
\hline Renewable energy PI (per year) & 4.08 & 6.80 & 0.00 & 51.00 & 3.63 & 5.61 & 0.00 & 30.00 \\
\hline Technology-push PI (per year) & 1.18 & 2.41 & 0.00 & 17.00 & 0.76 & 1.53 & 0.00 & 7.00 \\
\hline Demand-pull PI & 1.64 & 3.31 & 0.00 & 27.00 & 1.61 & 2.94 & 0.00 & 14.00 \\
\hline Systemic PI & 1.26 & 2.58 & 0.00 & 17.00 & 1.27 & 2.41 & 0.00 & 17.00 \\
\hline \multicolumn{9}{|l|}{ Total Government Budget Allocations (all } \\
\hline categories) (Million US\$ (2010 prices and PPP)) & 532.00 & 1091.07 & 1.70 & 9930.16 & 219.96 & 275.59 & 1.70 & 1284.97 \\
\hline Electricity Market Size (GWh) & 251,812 & 603,591 & 4,134 & $3,921,940$ & 116,282 & 139,813 & 4,134 & 547,284 \\
\hline Market Concentration - electricity markets (\%) & 54.91 & 25.61 & 15.30 & 100.00 & 56.10 & 25.81 & 15.30 & 100.00 \\
\hline
\end{tabular}


Table 2: Results for the OECD Specification

\begin{tabular}{|c|c|c|c|c|c|c|c|c|c|c|c|c|c|c|c|}
\hline \multirow[b]{2}{*}{$\begin{array}{c}\text { Policy and } \\
\text { control } \\
\text { variables \Innova } \\
\text { tion intensity }\end{array}$} & \multicolumn{5}{|c|}{ All OECD } & \multicolumn{5}{|c|}{ High Intervention OECD } & \multicolumn{5}{|c|}{ Low Intervention OECD } \\
\hline & Biofuel & $\begin{array}{c}\text { Geo- } \\
\text { thermal }\end{array}$ & Hydro & Solar & Wind & Biofuel & $\begin{array}{c}\text { Geo- } \\
\text { thermal }\end{array}$ & Hydro & Solar & Wind & Biofuel & $\begin{array}{c}\text { Geo- } \\
\text { thermal }\end{array}$ & Hydro & Solar & Wind \\
\hline Technology-push & $0.229^{* *}$ & 0.219 & $0.240^{* *}$ & $0.139 *$ & 0.086 & 0.231 & $0.548^{*}$ & $0.306^{*}$ & -0.0524 & -0.059 & $0.230^{*}$ & 0.0776 & $0.306^{* * *}$ & $0.210^{* *}$ & $0.184^{* *}$ \\
\hline PI & $(-2.58)$ & $(-1.52)$ & $(-3.26)$ & $(-2.39)$ & $(-1.57)$ & $(-1.21)$ & $(-2.14)$ & $(-2.36)$ & $(-0.45)$ & $(-0.61)$ & $(-1.98)$ & $(-0.4)$ & $(-3.84)$ & $(-3.13)$ & $(-3.01)$ \\
\hline \multirow[t]{2}{*}{ Demand-pull PI } & $0.168^{*}$ & 0.215 & $0.329 * * *$ & 0.102 & $0.226^{* * *}$ & $0.405^{* *}$ & $1.041^{* * *}$ & $0.577^{* * *}$ & $0.323^{* * *}$ & $0.316^{* * *}$ & 0.156 & -0.0255 & $0.204^{*}$ & -0.0036 & 0.0927 \\
\hline & $(-2.1)$ & $(-1.58)$ & $(-4.57)$ & $(-1.73)$ & $(-4.1)$ & $(-2.86)$ & $(-4.55)$ & $(-6.51)$ & $(-3.46)$ & $(-4.37)$ & $(-1.52)$ & $(-0.14)$ & $(-2.18)$ & $(-0.05)$ & $(-1.1)$ \\
\hline \multirow[t]{2}{*}{ Systemic PI } & -0.0527 & -0.000604 & -0.0187 & -0.0278 & $-0.0832^{*}$ & $-0.276^{*}$ & $-0.350^{* *}$ & $-0.217^{* *}$ & $-0.123^{* *}$ & $-0.111^{*}$ & 0.119 & 0.273 & 0.116 & 0.0902 & 0.0331 \\
\hline & $(-0.72)$ & $(-0.01)$ & $(-0.40)$ & $(-0.85)$ & $(-2.41)$ & $(-2.07)$ & $(-2.91)$ & $(-3.20)$ & $(-2.65)$ & $(-2.42)$ & $(-1.11)$ & $(-1.95)$ & $(-1.74)$ & $(-1.31)$ & $(-0.56)$ \\
\hline Market & -0.00612 & 0.00697 & $-0.00659^{*}$ & $-0.013^{* * *}$ & -0.00609 & -0.0151 & 0.0212 & -0.00809 & -0.0143 & -0.00795 & -0.00587 & 0.0165 & $-0.00950^{*}$ & $-0.0116 * *$ & -0.0053 \\
\hline Concentration & $(-1.37)$ & $(-1.00)$ & $(-2.00)$ & $(-3.82)$ & $(-1.93)$ & $(-1.40)$ & $(-1.91)$ & $(-1.69)$ & $(-1.95)$ & $(-1.47)$ & $(-0.90)$ & $(-1.5)$ & $(-2.27)$ & $(-2.81)$ & $(-1.23)$ \\
\hline Market Size & $(-4.45)$ & $(-3.21)$ & $(-4.42)$ & $(-1.14)$ & $(-5.05)$ & $(-3.96)$ & $(-1.99)$ & $(-2.31)$ & $(-0.46)$ & $(-3.05)$ & $(-0.34)$ & $(-0.71)$ & $(-2.43)$ & $(-0.88)$ & $(-2.47)$ \\
\hline \multirow[t]{2}{*}{ Kyoto dummy } & 0.154 & $0.879 * * *$ & $0.242^{* *}$ & $0.647^{* * *}$ & $0.450^{* * *}$ & -0.0178 & 0.222 & $0.279^{*}$ & $0.413^{* *}$ & $0.429^{* *}$ & 0.27 & $0.940^{* * *}$ & 0.156 & $0.664^{* * *}$ & $0.386^{* * *}$ \\
\hline & $(-1.2)$ & $(-5.39)$ & $(-2.65)$ & $(-6.96)$ & $(-5.64)$ & $(-0.11)$ & $(-1.13)$ & $(-2.21)$ & $(-2.6)$ & $(-3.04)$ & $(-1.57)$ & $(-4.28)$ & $(-1.37)$ & $(-5.19)$ & $(-3.74)$ \\
\hline Total & -0.0000373 & -0.0000324 & -0.0000407 & 0.0000039 & $-0.0000488^{*}$ & -0.0000473 & -0.0000415 & -0.0000495 & 0.0000025 & -0.0000363 & 0.000106 & 0.000019 & 0.0000148 & $-4.93 \mathrm{E}-06$ & -0.0000364 \\
\hline $\begin{array}{l}\text { Government } \\
\text { Budget }\end{array}$ & $(-1.34)$ & $(-1.07)$ & $(-1.90)$ & $(-0.17)$ & $(-2.50)$ & $(-1.31)$ & $(-1.04)$ & $(-1.72)$ & $(-0.09)$ & $(-1.38)$ & $(-1.64)$ & $(-0.26)$ & $(-0.38)$ & $(-0.10)$ & $(-0.78)$ \\
\hline Allocations & & & & & & & & & & & & & & & \\
\hline
\end{tabular}

All specifications include country fixed effects and year dummies. t-values in parentheses. ${ }^{* * *} \mathrm{p}<0.01,{ }^{* *} \mathrm{p}<0.05,{ }^{*} \mathrm{p}<0.1$. 
Table 3: Results for the OECD Specification, Adjusted for Quality

\begin{tabular}{|c|c|c|c|c|c|c|c|c|c|c|}
\hline \multirow[b]{2}{*}{$\begin{array}{c}\text { Policy and } \\
\text { control } \\
\text { variables \Inno } \\
\text { vation } \\
\text { intensity }\end{array}$} & \multicolumn{5}{|c|}{ High Intervention OECD } & \multicolumn{5}{|c|}{ Low Intervention OECD } \\
\hline & Biofuel & $\begin{array}{c}\text { Geo- } \\
\text { thermal }\end{array}$ & Hydro & Solar & Wind & Biofuel & $\begin{array}{c}\text { Geo- } \\
\text { thermal }\end{array}$ & Hydro & Solar & Wind \\
\hline Technology- & 0.448 & 0.319 & $0.998^{* * *}$ & 0.162 & $0.607^{* *}$ & 0.188 & $-1.322^{*}$ & -0.174 & -0.204 & -0.153 \\
\hline push PI & $(-1.56)$ & $(-0.59)$ & $(-3.43)$ & $(-0.62)$ & $(-2.81)$ & $(-0.7)$ & $(-1.97)$ & $(-0.65)$ & $(-0.81)$ & $(-0.90)$ \\
\hline Demand-pull & 0.385 & $1.221^{*}$ & $1.037^{* * *}$ & 0.0758 & $0.451^{*}$ & 0.244 & 0.0943 & 0.0997 & $-0.416^{*}$ & 0.0147 \\
\hline PI & $(-1.71)$ & $(-2.45)$ & $(-5.44)$ & $(-0.38)$ & $(-2.36)$ & -1.28 & -0.27 & -0.46 & $(-2.00)$ & -0.08 \\
\hline \multirow[t]{2}{*}{ Systemic PI } & -0.151 & -0.48 & $-0.996 * *$ & $-0.363^{* *}$ & $-0.614^{* *}$ & -0.195 & -0.362 & -0.252 & -0.133 & -0.207 \\
\hline & $(-0.75)$ & $(-1.13)$ & $(-6.06)$ & $(-2.60)$ & $(-3.00)$ & $(-1.07)$ & $(-1.50)$ & $(-1.48)$ & $(-0.74)$ & $(-1.55)$ \\
\hline Market & -0.00552 & $0.0535^{* *}$ & 0.0156 & -0.0133 & -0.0114 & -0.00104 & 0.0185 & $-0.0225^{* * *}$ & $-0.0142^{*}$ & $-0.0232^{* * *}$ \\
\hline Concentration & $(-0.37)$ & $(-2.78)$ & $(-1.36)$ & $(-1.09)$ & $(-1.02)$ & $(-0.12)$ & $(-1.32)$ & $(-3.68)$ & $(-2.08)$ & $(-3.57)$ \\
\hline Electricity & $0.0000123^{* *}$ & $0.0000182^{* * *}$ & $6.82 \mathrm{E}-06$ & $5.16 \mathrm{E}-06$ & $0.00000716^{*}$ & $-6.78 \mathrm{E}-06$ & $-2.75 \mathrm{E}-06$ & $3.89 E-06$ & $2.28 \mathrm{E}-06$ & $-2.48 \mathrm{E}-07$ \\
\hline Market Size & $(-3.02)$ & $(-3.37)$ & $(-1.86)$ & $(-1.61)$ & $(-1.97)$ & $(-1.25)$ & $(-0.42)$ & $(-0.84)$ & $(-0.5)$ & $(-0.06)$ \\
\hline \multirow[t]{2}{*}{ Kyoto dummy } & -0.113 & 0.163 & -0.0521 & 0.137 & 0.173 & -0.309 & $1.209 * *$ & $-0.715^{* *}$ & -0.158 & $-0.448^{*}$ \\
\hline & $(-0.37)$ & $(-0.46)$ & $(-0.19)$ & $(-0.46)$ & $(-0.8)$ & $(-1.09)$ & $(-3.2)$ & $(-3.22)$ & $(-0.60)$ & $(-2.22)$ \\
\hline Total & $-0.000176^{*}$ & $-0.000292^{* *}$ & $-0.000183^{*}$ & -0.0000613 & $-0.000192^{* *}$ & 0.00019 & 0.000233 & $3.93 \mathrm{E}-06$ & 0.0000082 & 0.000104 \\
\hline $\begin{array}{c}\text { Government } \\
\text { Budget } \\
\text { Allocations }\end{array}$ & $(-2.23)$ & $(-2.79)$ & $(-2.17)$ & $(-1.00)$ & $(-2.95)$ & $(-1.67)$ & $(-1.78)$ & $(-0.04)$ & $(-0.08)$ & $(-1.1)$ \\
\hline
\end{tabular}




\begin{tabular}{|c|c|c|c|c|c|c|c|c|c|c|c|c|c|c|c|}
\hline & & & All Europ & & & & High I & terventio & Europe & & & Low In & rvention & Europe & \\
\hline $\begin{array}{c}\text { Policy and } \\
\text { control } \\
\text { variables \Inno } \\
\text { vation } \\
\text { intensity }\end{array}$ & Biofuel & $\begin{array}{l}\text { Geo- } \\
\text { thermal }\end{array}$ & Hydro & Solar & Wind & Biofuel & $\begin{array}{l}\text { Geo- } \\
\text { ther } \\
\text { mal }\end{array}$ & Hydro & Solar & Wind & Biofuel & $\begin{array}{c}\text { Geo- } \\
\text { thermal }\end{array}$ & Hydro & Solar & Wind \\
\hline $\begin{array}{c}\text { Technology- } \\
\text { push PI }\end{array}$ & $\begin{array}{l}0.223^{*} \\
(-2.55)\end{array}$ & $\begin{array}{r}0.215 \\
(-1.55)\end{array}$ & $\begin{array}{l}0.226^{* *} \\
(-3.08)\end{array}$ & $\begin{array}{l}0.138^{*} \\
(-2.36)\end{array}$ & $\begin{array}{r}0.101 \\
(-1.81)\end{array}$ & $\begin{array}{r}0.24 \\
(-1.75)\end{array}$ & $\begin{array}{l}0.576^{*} \\
(-2.27)\end{array}$ & $\begin{array}{r}0.369^{* * *} \\
(-3.33)\end{array}$ & $\begin{array}{l}-0.113 \\
(-1.30)\end{array}$ & $\begin{array}{r}0.145 \\
(-1.66)\end{array}$ & $\begin{array}{l}0.232^{*} \\
(-2.19)\end{array}$ & $\begin{array}{r}0.0787 \\
(-0.5)\end{array}$ & $\begin{array}{r}0.285 * * * \\
(-3.79)\end{array}$ & $\begin{array}{l}0.178^{* *} \\
(-2.83)\end{array}$ & $\begin{array}{r}0.180^{* * *} \\
(-3.32)\end{array}$ \\
\hline $\begin{array}{l}\text { Demand-pull } \\
\qquad \text { PI }\end{array}$ & $\begin{array}{l}0.172^{*} \\
(-2.19)\end{array}$ & $\begin{array}{l}0.214 \\
(-1.58)\end{array}$ & $\begin{array}{r}0.363^{* * *} \\
(-5.07)\end{array}$ & $\begin{array}{l}0.107 \\
(-1.81)\end{array}$ & $\begin{array}{r}0.221^{* * *} \\
(-3.91)\end{array}$ & $\begin{array}{l}0.275^{*} \\
(-2.01)\end{array}$ & $\begin{array}{r}0.866^{* * *} \\
(-4.26)\end{array}$ & $\begin{array}{r}0.577^{* * *} \\
(-6.53)\end{array}$ & $\begin{array}{r}0.338^{* * *} \\
(-4.63)\end{array}$ & $\begin{array}{r}0.333^{* * *} \\
(-5.06)\end{array}$ & $\begin{array}{l}0.124 \\
(-1.25)\end{array}$ & $\begin{array}{r}-0.0622 \\
(-0.37)\end{array}$ & $\begin{array}{l}0.218^{*} \\
(-2.34)\end{array}$ & $\begin{array}{r}0.00262 \\
(-0.03)\end{array}$ & $\begin{array}{l}0.0213 \\
(-0.26)\end{array}$ \\
\hline Systemic PI & $\begin{array}{l}-0.0665 \\
(-0.90)\end{array}$ & $\begin{array}{r}0.00649 \\
(-0.08)\end{array}$ & $\begin{array}{r}-0.00813 \\
(-0.18)\end{array}$ & $\begin{array}{l}-0.0252 \\
(-0.77)\end{array}$ & $\begin{array}{r}-0.0696^{*} \\
(-2.00)\end{array}$ & $\begin{array}{r}- \\
0.281^{*} \\
(-2.04)\end{array}$ & $\begin{array}{r}-0.388^{* *} \\
(-3.08)\end{array}$ & $\begin{array}{l}-0.169^{*} \\
(-2.44)\end{array}$ & $\begin{array}{r}-0.139^{* * *} \\
(-3.38)\end{array}$ & $\begin{array}{r}-0.166 * * * \\
(-3.86)\end{array}$ & $\begin{array}{l}0.0595 \\
(-0.56)\end{array}$ & $\begin{array}{l}0.257 \\
(-1.84)\end{array}$ & $\begin{array}{l}0.130^{*} \\
(-2.06)\end{array}$ & $\begin{array}{r}0.0978 \\
(-1.5)\end{array}$ & $\begin{array}{l}0.0454 \\
(-0.78\end{array}$ \\
\hline $\begin{array}{c}\text { Market } \\
\text { Concentration }\end{array}$ & $\begin{array}{r}-0.00713 \\
(-1.60)\end{array}$ & 0.00489 & $\begin{array}{r}-0.00681^{*} \\
(-2.06)\end{array}$ & $\begin{array}{r}- \\
0.0125^{* * *} \\
(-3.72)\end{array}$ & $\begin{array}{r}-0.00552 \\
(-1.73)\end{array}$ & $\begin{array}{r}0.0010 \\
8 \\
(-0.12)\end{array}$ & $\begin{array}{r}0.0233^{*} \\
(-2.06)\end{array}$ & $\begin{array}{r}-0.00427 \\
(-0.91)\end{array}$ & $\begin{array}{r}-0.0131^{*} \\
(-2.44)\end{array}$ & $\begin{array}{r}-0.00717 \\
(-1.34)\end{array}$ & $\begin{array}{l}-0.0126 \\
(-1.82)\end{array}$ & $\begin{array}{r}0.0126 \\
(-1.1)\end{array}$ & $\begin{array}{r}-0.00832 \\
(-1.96)\end{array}$ & $\begin{array}{r}-0.0107^{*} \\
(-2.56)\end{array}$ & $\begin{array}{r}-0.000681 \\
(-0.16)\end{array}$ \\
\hline $\begin{array}{l}\text { Electricity } \\
\text { Market Size }\end{array}$ & $\begin{array}{r}0.00001^{* *} \\
* \\
(-4.54)\end{array}$ & $\begin{array}{r}0.000006^{*} \\
* \\
(-2.9)\end{array}$ & $\begin{array}{r}0.00001^{* *} \\
* \\
(-4.42)\end{array}$ & $\begin{array}{r}1.43 \mathrm{E}-06 \\
(-1.15)\end{array}$ & $\begin{array}{r}0.00001^{* * *} \\
(-5.09)\end{array}$ & $\begin{array}{r}0.0000 \\
1 * * * \\
(-4.64)\end{array}$ & $\begin{array}{r}4.95 \mathrm{E}-06 \\
(-0.86)\end{array}$ & $\begin{array}{r}0.000006^{*} \\
* \\
(-2.87)\end{array}$ & $\begin{array}{r}2.2 \mathrm{E}-06 \\
(-1.28)\end{array}$ & $\begin{array}{r}0.000005 * \\
* \\
(-2.79)\end{array}$ & $\begin{array}{r}-2.02 E-06 \\
(-0.47)\end{array}$ & $\begin{array}{r}0.00001^{*} \\
(-2.35)\end{array}$ & $\begin{array}{r}0.000008^{*} \\
* \\
(-3.03)\end{array}$ & $\begin{array}{r}0.000009 * \\
* \\
(-3.08)\end{array}$ & $\begin{array}{r}0.00001^{* *} \\
* \\
(-4.06)\end{array}$ \\
\hline Kyoto dummy & $\begin{array}{r}0.13 \\
(-1.03)\end{array}$ & $\begin{array}{r}0.830^{* * *} \\
(-5.1)\end{array}$ & $\begin{array}{r}0.248^{* *} \\
(-2.64)\end{array}$ & $\begin{array}{r}0.637^{* * *} \\
(-6.7)\end{array}$ & $\begin{array}{r}0.427^{* * *} \\
(-5.21)\end{array}$ & $\begin{array}{l}-0.135 \\
(-0.94)\end{array}$ & $\begin{array}{r}0.268 \\
(-1.35)\end{array}$ & & $\begin{array}{r}0.585^{* * *} \\
(-4.19)\end{array}$ & $\begin{array}{r}0.526^{* * *} \\
(-3.96)\end{array}$ & $\begin{array}{l}0.344^{*} \\
(-1.98)\end{array}$ & $\begin{array}{l}0.731^{* *} \\
(-3.19)\end{array}$ & & $\begin{array}{r}0.580^{* * *} \\
(-4.81)\end{array}$ & $\begin{array}{r}0.401^{* * *} \\
(-4.11)\end{array}$ \\
\hline $\begin{array}{l}\text { Total } \\
\text { Government } \\
\text { Budget } \\
\text { Allocations }\end{array}$ & $\begin{array}{r}-3.93 E-05 \\
(-1.42)\end{array}$ & $\begin{array}{r}-3.48 \mathrm{E}-05 \\
(-1.14)\end{array}$ & $\begin{array}{r}- \\
0.000044^{*} \\
(-2.05)\end{array}$ & $\begin{array}{r}3.94 \mathrm{E}-06 \\
(-0.17)\end{array}$ & $\begin{array}{r}-0.000045^{*} \\
(-2.54)\end{array}$ & $\begin{array}{r}-1.3 E- \\
05 \\
(-0.32)\end{array}$ & & $\begin{array}{r}-3.17 E-05 \\
(-1.01)\end{array}$ & $\begin{array}{r}1.87 E-05 \\
(-0.62)\end{array}$ & $\begin{array}{r}-1.23 \mathrm{E}-05 \\
(-0.42)\end{array}$ & $\begin{array}{r}0.0000648 \\
(-1.00)\end{array}$ & & $\begin{array}{r}1.23 E-05 \\
(-0.32)\end{array}$ & $\begin{array}{r}0.000014 \\
(-0.3)\end{array}$ & $\begin{array}{r}-2.33 E-05 \\
(-0.53)\end{array}$ \\
\hline $\begin{array}{l}\text { North of } \\
\text { Europe }\end{array}$ & & & & & & $\begin{array}{r}3.590 * \\
* \\
(-2.85)\end{array}$ & $\begin{array}{l}13.07 \\
(-0.02)\end{array}$ & $\begin{array}{r}1.177 \\
(-1.68)\end{array}$ & $\begin{array}{r}2.054^{* * *} \\
(-3.39)\end{array}$ & $\begin{array}{l}1.586^{* *} \\
(-3.07)\end{array}$ & $\begin{array}{r}-1.166^{* *} \\
(-2.78)\end{array}$ & $\begin{array}{l}-0.915 \\
(-1.15)\end{array}$ & $\begin{array}{l}-0.535 \\
(-1.80)\end{array}$ & $\begin{array}{l}-0.373 \\
(-1.26)\end{array}$ & $\begin{array}{l}-0.644^{*} \\
(-2.24)\end{array}$ \\
\hline $\begin{array}{l}\text { South of } \\
\text { Europe }\end{array}$ & & & & & & $\begin{array}{r}1.988 \\
(-1.78)\end{array}$ & $\begin{array}{l}-1.423 \\
(-0.86)\end{array}$ & $\begin{array}{l}1.133 \\
(-1.52)\end{array}$ & $\begin{array}{l}1.897^{* *} \\
(-2.84)\end{array}$ & $\begin{array}{r}2.364^{* * *} \\
(-3.93)\end{array}$ & $\begin{array}{r}1.817 \\
(-0.93)\end{array}$ & $\begin{array}{l}-3.004 \\
(-1.95)\end{array}$ & $\begin{array}{l}-1.315 \\
(-1.52)\end{array}$ & $\begin{array}{r}-2.746^{* * *} \\
(-3.35)\end{array}$ & $\begin{array}{r}-2.666^{* *} \\
(-3.16)\end{array}$ \\
\hline
\end{tabular}

All specifications include country fixed effects and year dummies. $t$-values in parentheses. $* 3: 2 \mathrm{p}<0.01, * * \mathrm{p}<0.05, * \mathrm{p}<0.1$. 
Table 5: Results for the Europe Specification, Adjusted for Quality

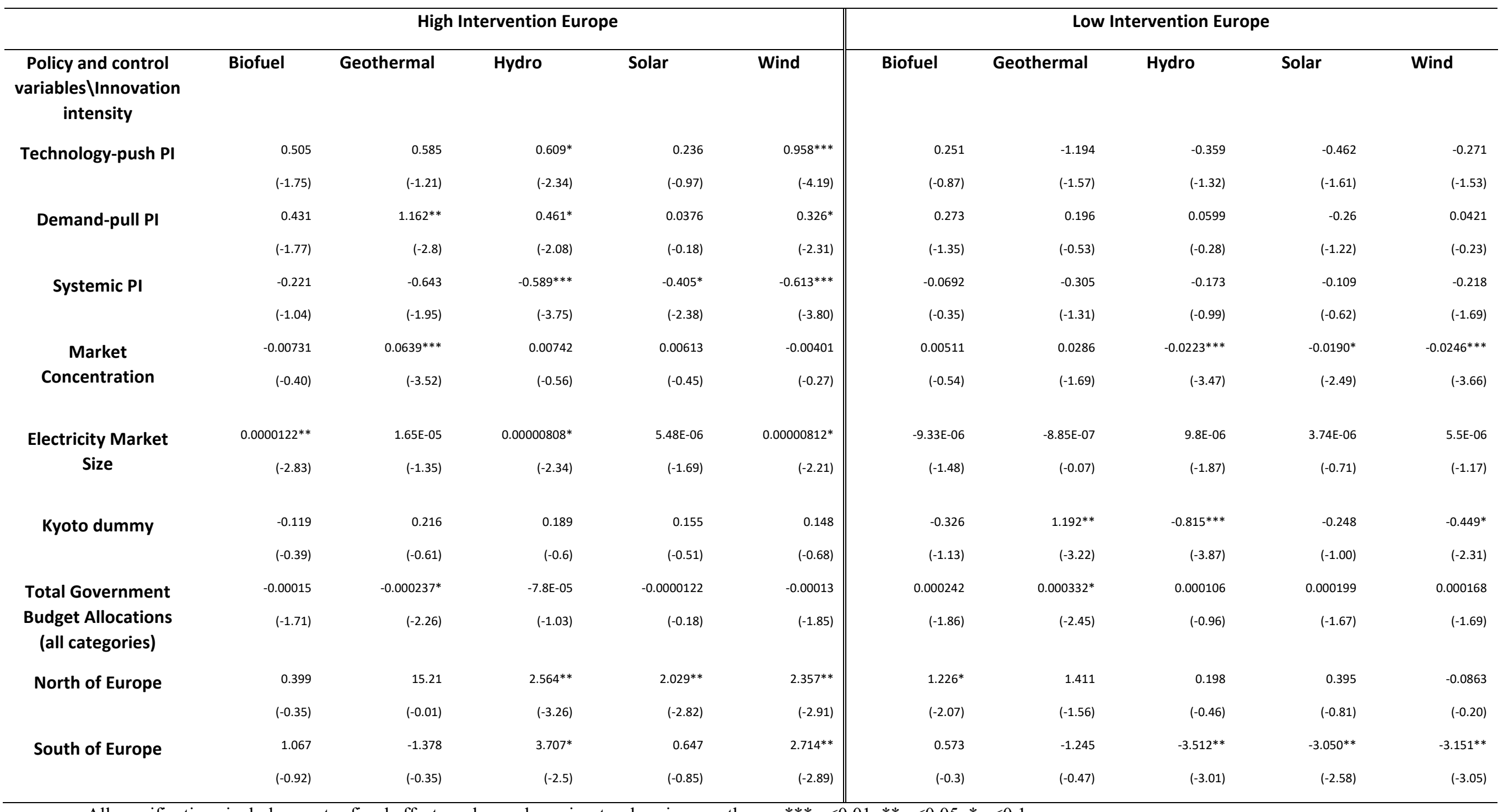

All specifications include country fixed effects and year dummies. t-values in parentheses. ${ }^{* * *} \mathrm{p}<0.01,{ }^{* *} \mathrm{p}<0.05,{ }^{*} \mathrm{p}<0.1$. 


\begin{tabular}{|c|c|c|c|}
\hline Research Hypothesis & Result & Estimation results & Policy implications \\
\hline $\begin{array}{l}\text { H1: REP instruments } \\
\text { positively affect } R E \\
\text { technologies. }\end{array}$ & $\begin{array}{l}\text { Overall positive and significant effect across most RET. Policy } \\
\text { intervention has been effective in stimulating more innovation } \\
\text { activity in RET. }\end{array}$ & Table 2: Results for the OECD Specification & $\begin{array}{l}\text { In order to improve its efficacy in fostering } \mathrm{RE} \\
\text { innovation, public policy makers should select the } \\
\text { appropriate instrument, or instrument mix thereof. }\end{array}$ \\
\hline $\begin{array}{l}\text { H2: The effect of REP } \\
\text { instruments on RETs } \\
\text { varies between specific } \\
\text { instruments and RETs. }\end{array}$ & $\begin{array}{l}\text { Technology-push policy instruments have been more effective } \\
\text { in fostering innovation in biofuel, hydro and solar -related } \\
\text { technologies. Demand - pull policy instruments have been more } \\
\text { effective in stimulating innovation in biofuel, hydro, and wind- } \\
\text { related technologies. Systemic policy instruments are found to } \\
\text { have a significant effect only when controlling for quality of } \\
\text { innovation. }\end{array}$ & $\begin{array}{l}\text { Table 2: Results for the OECD Specification } \\
\text { Table 4: Results for the Europe specification }\end{array}$ & $\begin{array}{l}\text { To increase policy impact, policy-makers should use a } \\
\text { REP mix that mirrors the type of RET they wish to } \\
\text { target. Our results provide a guide to aid with this } \\
\text { choice (tables } 1 \text { and } 2 \text { ). }\end{array}$ \\
\hline $\begin{array}{l}\text { H3: The impact of } \\
\text { targeting particular RETs } \\
\text { on RE innovation is } \\
\text { mediated by a country's } \\
\text { experience. }\end{array}$ & $\begin{array}{l}\text { Experience in practicing industrial policy matters. When } \\
\text { distinguish between "high" and "low" policy intervention } \\
\text { groups of countries, we find consistently that REP are more } \\
\text { likely to have a significant (and more sizeable) effect when } \\
\text { used in the "high intervention" group. }\end{array}$ & $\begin{array}{l}\text { Table 2: Results for the OECD Specification } \\
\text { Table 4: Results for the Europe specification }\end{array}$ & $\begin{array}{l}\text { Policy makers can learn from mistakes. The possibility } \\
\text { for and fear of mistakes is no justification for inaction. } \\
\text { Experience and learning matter. }\end{array}$ \\
\hline $\begin{array}{l}\text { H4: The efficacy of } \\
\text { targeting RETs differs } \\
\text { across North-South EU } \\
\text { regions. }\end{array}$ & $\begin{array}{l}\text { Policy intervention is more effective in northern than in } \\
\text { southern EU member states. This result holds for both "high" } \\
\text { and "low" intervention groups. These differences become even } \\
\text { more pronounced when controlling for quality of innovation. }\end{array}$ & $\begin{array}{l}\text { "Table 4: Results for the Europe specification } \\
\text { Table 5: Results for the Europe specification, adjusted } \\
\text { for quality }\end{array}$ & $\begin{array}{l}\text { REPs tend to work better within a context of } \\
\text { supporting governance structures. }\end{array}$ \\
\hline $\begin{array}{l}\text { H5: Public support for } \\
\text { particular RETs impairs } \\
\text { (negatively affects) the } \\
\text { quality of the RET } \\
\text { innovations. }\end{array}$ & $\begin{array}{l}\text { The use of policy support instruments in the OECD over our } \\
\text { sample period has been much less effective in encouraging } \\
\text { impactful innovation in RE technologies than it had in } \\
\text { stimulating activity per se. }\end{array}$ & $\begin{array}{l}\text { Table 3: Results for the OECD specification, adjusted } \\
\text { for quality } \\
\text { Table 5: Results for the Europe specification, adjusted } \\
\text { for quality }\end{array}$ & $\begin{array}{l}\text { Policy makers should design and evaluate the impact } \\
\text { of policies to ensure that that these do not engender } \\
\text { lower quality innovations aimed to take advantage of } \\
\text { government funding. }\end{array}$ \\
\hline
\end{tabular}




\section{Endnotes}

' Australia, Austria, Belgium, Canada, Chile, Czech Republic, Denmark, Estonia, Finland, France, Germany, Greece, Hungary, Ireland, Israel, Italy, Japan, Korea, Latvia, Luxembourg, Mexico, Netherlands, New Zealand, Norway, Poland, Portugal, Slovakia, Slovenia, Spain, Sweden, Switzerland, Turkey, United Kingdom and United States.

ii Despite criticisms often attributed to the use of patent statistics as a measure of innovation activity, it is widely argued that their advantages overshadow their disadvantages. For an extensive review of patent statistics, see OECD (2005). 